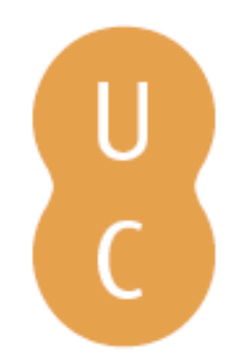

\title{
nombalina
}

\section{John stuart Mill, A «tirania da maioria» e o seu futuro}

Autor(es): $\quad$ Sá, Alexandre Franco de

Publicado por: Imprensa da Universidade de Coimbra

URL persistente:

URI:http://hdl.handle.net/10316.2/31699

DOI:

DOI:http://dx.doi.org/10.14195/978-989-26-0204-2_6

Accessed : $\quad$ 26-Apr-2023 16:15:56

A navegação consulta e descarregamento dos títulos inseridos nas Bibliotecas Digitais UC Digitalis, UC Pombalina e UC Impactum, pressupõem a aceitação plena e sem reservas dos Termos e Condições de Uso destas Bibliotecas Digitais, disponíveis em https://digitalis.uc.pt/pt-pt/termos.

Conforme exposto nos referidos Termos e Condições de Uso, o descarregamento de títulos de acesso restrito requer uma licença válida de autorização devendo o utilizador aceder ao(s) documento(s) a partir de um endereço de IP da instituição detentora da supramencionada licença.

Ao utilizador é apenas permitido o descarregamento para uso pessoal, pelo que o emprego do(s) título(s) descarregado(s) para outro fim, designadamente comercial, carece de autorização do respetivo autor ou editor da obra.

Na medida em que todas as obras da UC Digitalis se encontram protegidas pelo Código do Direito de Autor e Direitos Conexos e demais legislação aplicável, toda a cópia, parcial ou total, deste documento, nos casos em que é legalmente admitida, deverá conter ou fazer-se acompanhar por este aviso. 
Carlos Camponez

Ana Teresa Peixinho

Coordenação

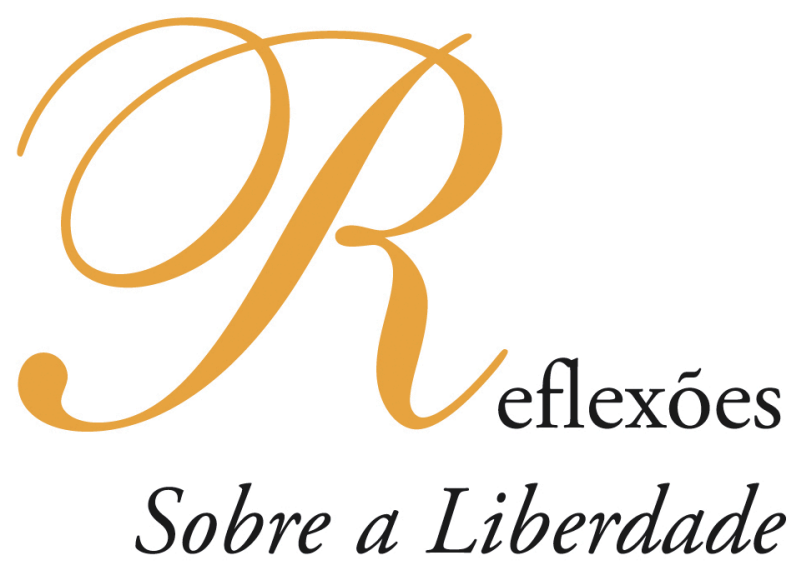

150 anos da obra de John Stuart Mill

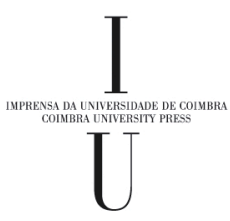




\section{John STUART Mill, \\ A «TiRANiA DA MAIORIA» E O SEU FUTURo}

Alexandre Franco de Sá

O livro On Liberty de John Stuart Mill, cuja publicação há cento e cinquenta anos comemoramos, constitui indubitavelmente, antes de mais, um marco fundamental na defesa social e política da Liberdade humana. Com a publicação de On Liberty, em 1859, o pensamento filosófico dava um passo essencial naquilo a que Fichte tinha chamado a «reivindicação da liberdade de pensar», estendendo-se para além da mera exigência de um poder político que, no seu exercício, soubesse ser limitado e tolerante. Vários pensadores, de Espinosa a Locke, de Voltaire a Kant, tinham defendido já, sob vários argumentos, a necessidade de o poder das magistraturas políticas não ser usado para a eliminação da liberdade individual dos homens, da sua liberdade de religião, de pensamento e de expressão, devendo, portanto, restringir-se e moderar-se a si mesmo no seu exercício. Destacando-se destes, Stuart Mill defenderá que a mera neutralidade política não é suficiente para o imprescindível reconhecimento do direito dos homens à Liberdade e que um tal reconhecimento não pode deixar de implicar, náo apenas uma atitude de tolerância por parte dos magistrados políticos relativamente às crenças, doutrinas e pensamentos de cada homem, mas também e sobretudo um empenho destes mesmos magistrados para que as circunstâncias da vida social não tornem, na prática, insuportável a sua expressão. Contudo, se $O n$ Liberty constitui um marco essencial no percurso do reconhecimento da Liberdade humana, dir-se-ia também que o modo como aqui se procede a este reconhecimento náo pode deixar de nos surgir hoje como caracterizado por limitaçóes intrínsecas. É o alcance da obra na tematização da questão da Liberdade, assim como as suas limitaçóes nesta tematização, que aqui procuraremos brevemente considerar.

Um primeiro aspecto que distingue On Liberty, na sua tematização da Liberdade humana, encontra-se na clareza e coerência com que na obra é enunciada a sua tese fundamental. Esta tese repousa na afirmação de um princípio absolutamente claro, transparente e inequívoco para que a esfera da liberdade individual seja separada do campo de possibilidades de uma intervenção legítima por parte de qualquer poder exterior. Stuart Mill enuncia um tal princípio determinante da esfera de uma liberdade individual inviolável e irredutível nos seguintes termos:

«Este princípio é o de que o único fim para o qual a humanidade está autorizada, individual ou colectivamente, a interferir na liberdade de acção de qualquer um dos seus, é a autoprotecção. Que o único propósito para o qual o poder pode ser legitimamente exercido sobre qualquer membro de uma comunidade civilizada, contra a sua vontade, é o de evitar danos para os outros. O seu próprio bem, seja físico ou moral, não é suficiente como autorização. [...] Na parte que meramente lhe concerne, a sua independência é, de direito, absoluta. Sobre ele mesmo, sobre o seu próprio corpo e mente, o indivíduo é soberano» (Mill, 1998: 14).

Assim, segundo o princípio enunciado por Mill, dir-se-ia que um indivíduo, uma vez adulto e em condiçóes normais de desenvolvimento, apenas poderia ser limitado na sua 
liberdade - na livre expressão e na livre vivência das suas crenças, dos seus pensamentos, dos seus hábitos e dos seus gostos - se essa mesma liberdade se constituísse como nociva para os outros. O enunciado por Mill do princípio da liberdade individual baseia-se, então, poderse-ia dizer, na distinção clara e inequívoca de dois tipos de acçôes e de opiniốes. No caso de acçóes e mesmo de opiniốes individuais que conduziriam a acçóes nocivas para terceiros, os magistrados políticos e a sociedade poderiam e deveriam intervir legitimamente no sentido de restringir ou mesmo anular essas acçôes, assim como de impedir a expressão pública de opinióes que a elas conduzissem. Contudo, no caso em que uma acçáo teria influência apenas na vida do indivíduo que a praticasse, e na circunstância em que a expressão de uma opinião não teria efeitos senão na existência do indivíduo que a professasse, esta acção e esta opinião deveriam ser essencialmente livres, sendo deixadas indeterminadas por instâncias públicas e sociais. Como conclui Stuart Mill:

«Ninguém pretende que as acçôes deveriam ser tão livres quanto as opiniōes. Pelo contrário, mesmo as opiniốes perdem a sua imunidade, se as circunstâncias nas quais são expressas são tais que a sua expressão constituiria uma instigação positiva a algum acto maldoso. [...] A liberdade do indivíduo deve ser muito limitada; ele não pode tornar-se nocivo para outros. Mas se evitar molestar os outros naquilo que lhes concerne, e se agir meramente de acordo com a sua inclinação e juízo em coisas que lhe concernem, as mesmas razóes que mostram que a opinião deve ser livre provam também que lhe devia ser permitido, sem ser molestado, às suas próprias custas, levar as suas opiniôes à prática» (Mill, 1998: 62-63).

Se On Liberty se distingue, antes de mais, pela clareza do enunciado do princípio de que parte, a fundamentaçáo deste princípio constitui um segundo aspecto essencial pelo qual a obra pode ser destacada como um marco fundamental na defesa da Liberdade humana. A defesa de que os homens deveriam ser, em assuntos que só afectariam a sua individualidade, essencialmente livres, indeterminados por quaisquer poderes exteriores, justifica-se para Stuart Mill, antes de mais, pela evocação da condição finita e falível do homem. É a evocação desta falibilidade como marca fundamental da natureza humana, afirmada por Stuart Mill com a clareza possível diante das teses utilitaristas de Jeremy Bentham e do seu pai James Mill, que lhe permite a conclusão não só de que não é possível a um homem estar absolutamente certo e seguro de se encontrar na posse de uma verdade absoluta e definitiva, mas também de que, mesmo havendo por parte desse mesmo homem uma tal convicção, esta não poderia constituir uma justificaçáo suficiente para que ele forçasse outros homens a aceitarem essa mesma verdade. Como escreve Mill:

«Não é o sentir-se seguro de uma doutrina (seja ela qual for) aquilo a que chamo uma assunção de infalibilidade. É propor-se decidir essa questão pelos outros, sem lhes permitir ouvirem o que pode ser dito do lado contrário. E não denuncio nem reprovo menos essa pretensão se ela for reivindicada do lado das minhas mais solenes convicçôes» (Mill, 1998: 28).

O argumento esboçado por Stuart Mill na defesa de que a convicção de um homem sobre a sua verdade náo o justifica na sua eventual tentativa de a impor aos outros homens é aqui decisivo. Este argumento tem dois lados que importa diferenciar e tornar explícitos. Por um lado, a tentativa de impor aos outros uma verdade corresponderia, segundo Mill, a uma concepção da natureza humana na qual o homem seria considerado como um ente 
determinado por um fim pré-estabelecido, invariável e apreensível cientificamente. Diante de uma tal determinação do homem por um fim que escapa à sua liberdade, determinaçáo essa pela qual seria possível a pretensáo de constituir um modelo de comportamento previsível, assim como uma educação totalmente programável e uma ética cientificamente fundada, Mill afirma claramente:

«A natureza humana não é uma máquina a ser construída de acordo com um modelo, e montada para fazer exactamente o trabalho que lhe é prescrito, mas uma árvore que requer crescer e desenvolver-se para todos os lados, de acordo com a tendência e as forças interiores que fazem dela uma coisa viva» (Mill, 1998: 66).

Contudo, por outro lado, mais do que pressupor uma visão redutora da natureza humana, a tentativa de impor aos outros uma verdade tida por absoluta, na medida em que corresponderia à pura e simples eliminação de qualquer juízo crítico e de qualquer confrontação dessa verdade com verdades alternativas, corresponderia igualmente ao enfraquecimento da própria verdade que se pretenderia impor. É então em função da própria conservação da verdade como verdade viva e actuante na existência humana que, para Stuart Mill, a liberdade de expressão de uma opinião falsa deveria ser garantida. Neste sentido, Mill afirma claramente:

"Mesmo que uma opinião recebida seja não apenas verdadeira, mas toda a verdade; a não ser que ela seja, e seja actualmente, contestada vigorosa e honestamente, ela será mantida, por muitos dos que a recebem, à maneira de um preconceito, com pouca compreensão ou sentimento dos seus fundamentos racionais. E não apenas isso, mas o significado da própria doutrina correrá o risco de ser perdido, ou enfraquecido, e privado do seu efeito vital no carácter e na conduta: tornando-se o dogma uma mera profissão de fé formal, ineficaz para o bem, mas tapando o fundamento, e impedindo o crescimento de qualquer convicçáo real e sentida a partir da razão e da experiência pessoal» (Mill, 1998: 59).

Este último lado do argumento esboçado por Stuart Mill é decisivo, na medida em que é ele que mais plenamente revela o alcance da sua reivindicação de um direito do indivíduo humano falível à liberdade. Um tal argumento não discute se é possível ou não a um qualquer indivíduo, honesta e autenticamente convicto do carácter absoluto de uma verdade, estar efectivamente na posse de uma verdade absoluta. Independentemente do carácter ilusório que uma tal convicção possa oferecer, em virtude da falibilidade constitutiva da natureza humana, o que aqui está em causa, para Mill, não é o conteúdo dessa mesma verdade, mas o modo como esta é vivida por aquele que a proclama como tal. Segundo Mill, mais do que impedir o acesso a uma verdade absoluta, acesso esse que, sendo problemático, também não poderá ser proclamado como intrínseca ou constitutivamente impossível, o que a falibilidade humana determina consiste no facto de uma verdade náo poder deixar de ser afectada pelo modo como é assumida pelo homem que a proclama. Assim, segundo Mill, uma verdade imposta dogmaticamente e aceite acriticamente através da eliminação de qualquer confrontação com verdades alternativas, ainda que seja em si mesma uma verdade "verdadeira», e "verdadeira" em termos absolutos, perder-se-á fatalmente, com o passar do tempo, na força da sua convicção, e adquirirá crescentemente o estatuto de um mero dogma exterior à vida. Tal quer dizer que, para Mill, o valor de uma verdade não se esgota no seu eventual conteúdo verdadeiro, mas repousa, para além deste, no grau de crítica e de 
liberdade com que este conteúdo é proclamado. Poder-se-ia até dizer que, para Mill, desde que não resulte numa violaçáo da Liberdade e dos direitos de terceiros, um erro proclamado crítica e autenticamente, correspondendo a uma convicção genuína, valeria mais e seria pelo menos tấo digno de ser expresso livremente quanto uma verdade desvitalizada que fosse professada mecanicamente como um dogma exterior, alheio à vida na sua efectividade.

Esta subordinaçáo do valor de uma verdade ao modo como esta verdade é vivida e assumida é, então, o elemento fundamental que permite associar a defesa da Liberdade por Stuart Mill a uma posição política particular. Dir-se-ia que, para Mill, a defesa da Liberdade se orienta politicamente para a meta da formação de homens críticos e tolerantes, dispostos a subordinar as suas convicçóes próprias ao exame da crítica, abertos a escutar os outros e mesmo a ser persuadidos pelas suas razóes, da mesma forma que capazes de defender as suas próprias convicçóes com razoabilidade e sem dogmatismos diante destas mesmas razóes. Para Mill, a defesa de que cada um possa ser tal como a sua individualidade exige, expressando nos mais variados domínios, as características dessa mesma individualidade, está orientada não propriamente para aumentar a verdade e diminuir o erro no seio da sociedade, isto é, não propriamente para multiplicar o número de indivíduos que professam doutrinas verdadeiras, mas para aumentar o número de indivíduos que, independentemente do conteúdo das doutrinas que professam, o fazem de um modo crítico, tolerante, aberto e inteligente, assumindo as suas convicçóes e pensamentos, gostos e sentimentos, pelo facto de serem autenticamente seus e não por corresponderem às convicçóes, pensamentos, gostos e sentimentos da «maioria moral» presente na sociedade. É para expressar que o fim da formação dos homens deveria consistir não na sua uniformização doutrinal, mas precisamente no livre desenvolvimento das suas vocaçôes e tendências individuais, que Stuart Mill evoca aqui o conceito de "génio» como expressão de uma meta implícita da formação humana. Longe de ser determinado por um conteúdo comum e uniforme, o génio é precisamente aquela figura humana que se constitui como radicalmente singular no seu modo de ser. E é sob a referência implícita à necessidade política de alimentar e cultivar uma educação que tenha a singularidade do génio como ideia reguladora que Mill escreve:

«As pessoas de génio, é verdade, são, e deverão sempre ser, uma pequena minoria; mas para as ter, é preciso preservar o solo no qual crescem. O génio só pode respirar livremente numa atmosfera de liberdade. As pessoas de génio são, ex vi termini, mais individuais que quaisquer outras - menos capazes, consequentemente, de se adequar, sem uma compressão dolorosa, a qualquer um dos pequenos moldes que a sociedade providencia para poupar aos seus membros o trabalho de formar o seu próprio carácter» (Mill, 1998: 72).

Nesta alusão à necessidade política de cultivar socialmente um génio singularizante, a análise de Mill desenvolve-se, por outro lado, num duplo momento que deve também ser diferenciado. Em primeiro lugar, ela procede a um diagnóstico da sociedade do seu tempo, enraizando-se nele e mostrando como uma tal sociedade se caracteriza, nas suas práticas, por coarctar a liberdade individual. Em segundo lugar, ela procura enfrentar um tal diagnóstico e responder à falta de liberdade que denuncia.

Assim, por um lado, é reflectindo sobre o ambiente social em que se encontra que Stuart Mill o caracteriza como uma «mediocridade colectiva». Segundo Mill, a atmosfera social da sociedade sua contemporânea seria marcada precisamente pela tendência para uma tal normalização massificadora da vida humana, traduzida na valorização social de todo um conjunto 
de práticas e discursos homogeneizadores. Ao caracterizar uma tal atmosfera, Mill oferece, aliás, um retrato muito eloquente, que é interessante aqui reproduzir na íntegra:

«Presentemente, os indivíduos estão perdidos na multidão. Em política, é quase uma trivialidade dizer que a opinião pública governa agora o mundo. $\mathrm{O}$ único poder que merece esse nome é o das massas, e o dos governos enquanto se convertem a eles mesmos no órgão das tendências e instintos das massas. [...] Parece, contudo, que quando as opinióes das massas de homens meramente medianos se tornaram ou estão a tornar em todo o lado o poder dominante, o contrapeso e o correctivo dessa tendência seria a cada vez mais pronunciada individualidade daqueles que estão nas mais altas eminências do pensamento. Nestas circunstâncias, é muito especial que os indivíduos excepcionais, em vez de serem impedidos, sejam encorajados a agir diferentemente da massa. Em outros tempos, não haveria vantagem em eles o serem, a não ser que agissem não apenas diferentemente, mas melhor. Nesta Era, o mero exemplo da nãoconformidade, a mera recusa em dobrar o joelho ao costume, é ele mesmo um serviço. Precisamente porque a tirania da opiniáo é de tal modo a fazer da excentricidade algo reprovável, é desejável, de maneira a quebrar tal tirania, que as pessoas sejam excêntricas» (Mill, 1998: 74).

E é então nesta leitura da sua contemporaneidade, assim como no papel que nela desempenha uma "mediocridade colectiva», que Mill encontra, por outro lado, o fundamento último para a sua proposta política essencial: a proposta de que, longe de se limitar a não interferir na esfera da sociedade, a tarefa legislativa do poder político deveria interferir nela no sentido de impedir que essa mesma sociedade, na sua maioria moral, se constituísse como um impedimento para a livre expressão da individualidade de cada um.

Assim, segundo Mill, para a defesa da liberdade individual de cada um, não bastaria reivindicar que o Estado reconhecesse na esfera privada dos cidadãos um domínio de liberdade que deveria permanecer vedado à possibilidade da sua intervenção política, do mesmo modo que não seria suficiente que o Estado fosse representativo ou democrático, assumindo junto do governo uma instância parlamentar que estaria incumbida de representar a sociedade junto do Estado. Mais do que um Estado circunscrito e limitado diante da esfera privada dos cidadãos, ou mais do que um governo democrático que reconhecesse a soberania do povo, ou pelo menos a necessidade da sua subordinação a instituiçóes representativas desse mesmo povo, a Liberdade exigiria que o Estado fosse determinado por regras e leis destinadas a impedir a própria sociedade, na sua maioria moral, de discriminar indivíduos excêntricos ou de proibir-lhes a livre expressão das suas doutrinas e dos seus pensamentos, das suas opinióes e dos seus gostos minoritários, desde que tais doutrinas, pensamentos, opinióes e gostos dissessem respeito apenas à sua individualidade, ou seja, desde que, independentemente da repulsa que pudessem causar na maioria dos seus concidadãos, não se constituíssem como nocivos para a vida destes. Face à tendência democrática para encontrar nos consensos ou nas maiorias um critério para a verdade e a correcção, Mill manifesta assim as maiores reservas quanto a conceitos democráticos como «soberania do povo» e «vontade geral»:

«A vontade do povo quer dizer, na prática, a vontade da parte do povo mais numerosa ou mais activa; a maioria, ou aqueles que são bem sucedidos em fazerem-se aceitar como a maioria; o povo, consequentemente, pode desejar oprimir uma parte do seu número; e é preciso tantas precauçôes contra isso como contra qualquer outro abuso de poder» (Mill, 1998: 8). 
E é, então, essencialmente diante da representação de uma «tirania da maioria» que toda a obra se articula, ganhando consistência como um manifesto em defesa da liberdade individual face aos costumes e hábitos das massas, ou face aos pensamentos e gostos impostos pela maioria dos homens presentes na sociedade. O fio condutor de On Liberty é, por isso, apresentado por Stuart Mill desde o início da obra:

«Tal como outras tiranias, a tirania da maioria foi a princípio, e ainda é vulgarmente, mantida através do medo, operando sobretudo através dos actos das autoridades públicas. Contudo, reflectindo, as pessoas perceberam que quando a sociedade é ela mesma o tirano - a sociedade colectivamente, acima dos indivíduos separados que a compóem - os seus meios de tiranizar não são restritos aos actos que ela pode fazer pelas mãos dos seus funcionários políticos. A sociedade pode executar, e executa de facto, os seus próprios mandatos: e se ela estabelece mandatos errados e náo certos, ou quaisquer mandatos em coisas nas quais não se deveria intrometer, ela pratica uma tirania social mais formidável do que qualquer tipo de opressão política, na medida em que, embora náo sustentada usualmente por tais penalidades extremas, deixa menos meios de escape, penetrando muito mais profundamente nos detalhes da vida e escravizando a própria alma» (Mill, 1998: 8-9).

A concepção de uma tirania da maioria diante da qual seria necessário guardar a Liberdade dos homens, ou seja, a concepção de que o maior perigo para esta Liberdade se encontra já não tanto num despotismo do Estado e do governo como numa tirania simultaneamente mais discreta e mais poderosa - porque exercida por meios mais subtis do que a coerção violenta que se encerra num uso explícito da força - é então a concepção que mais claramente marca o alcance e a originalidade da reflexáo desenvolvida por Mill em torno da Liberdade. No entanto, importa notar também que, ao mesmo tempo que marca maximamente este alcance e esta originalidade, a concepção de uma tirania da maioria assinala também ao pensamento desenvolvido por Mill os seus mais claros limites, na medida em que a apresentação que deste conceito é feita permanece encerrada no século XIX, subtraindo-se inteiramente, nessa medida, à antecipação do desenvolvimento que ele terá no século posterior. Daí que Isaiah Berlin, em John Stuart Mill and the Ends of Life, num texto que há cinquenta anos comemorava o centenário da publicaçáo de On Liberty, tenha razão quando nota:

«Mill não tinha quase nenhum dote profético. Ao contrário dos seus contemporâneos Marx, Burckhardt, Tocqueville, ele não tinha nenhuma visão daquilo que o século xx traria, nem das consequências políticas e sociais da industrialização, nem da descoberta da força dos factores irracionais e inconscientes no comportamento humano, nem das técnicas aterradoras para as quais este conhecimento conduziu e está a conduzir» (Berlin, 2004: 227-228).

Na medida em que a análise de Mill ficou encerrada na representação da tirania da sociedade sobre a liberdade individual como uma simples coerção social do vulgo, ela ignorou que, no século $\mathrm{XX}$, o futuro de uma tal tirania social consistiria precisamente na atribuição a minorias sociais politicamente activas e crescentemente mobilizadas do papel homogeneizador, nivelador e normalizador que Mill não podia ainda deixar de encarar como o atributo inevitável de uma maioria moral instalada socialmente. Dir-se-ia que, em larga medida, o século XX é constituído pela transformação da tirania social de uma maioria 
moral, diante da qual Mill reivindica o direito à liberdade individual, na tirania de minorias sociais que, mobilizadas pelo projecto de uma transformação mais ou menos radical da própria sociedade, se propóem transformar os homens individuais nela presentes através de uma determinaçáo das suas opinióes, dos seus pensamentos e mesmo da sua sensibilidade por meio de técnicas muito mais invasivas, em relação à liberdade individual de cada um, do que a simples coerção social dos costumes poderia alguma vez ter esperado realizar. E é, então, no enquadramento desta transformação da tirania social da maioria - com a qual On Liberty se confronta - em várias formas, mais ou menos subtis, de tirania social de minorias, características da história do século XX, que a reflexão de Mill adquire a sua possível actualidade. Trata-se de saber de que forma é possível dirigir os argumentos de Mill em favor da liberdade individual, diante da tirania social dos costumes aceites pela maior parte de uma população, contra as tentativas posteriores de submeter essa mesma liberdade individual à acção de técnicas de normalização da opinião, do pensamento e da sensibilidade utilizadas por minorias sociais mobilizadas para a transformação da própria sociedade. Um tal «uso» do pensamento de Mill é possível, mas não pode ignorar que os dois conceitos de «tirania da maioria» e de "tirania de minorias» têm graus de complexidade diferentes. Se a concepção de uma "tirania da maioria» é algo inequívoco, e se a representação da coerção moral dos indivíduos por parte dos costumes de amplas maiorias sociais é algo fácil de determinar, já a concepção de uma «tirania de minorias» abrange a possibilidade de configuraçôes muito diversificadas que não são pacificamente reconduzíveis a uma estrutura comum.

Foi sobretudo a partir da década de 1920 que pensadores como Edward Bernays chamaram a atenção para o imparável desenvolvimento de técnicas conducentes a uma crescente determinação da "opiniấo pública» da grande maioria da população, assim como da vontade e dos afectos das «massas», por uma "elite» minoritária capaz ou de dominar essas mesmas técnicas ou de controlar política e economicamente o seu uso. Dir-se-ia, então, que, no século XX, a passagem da tirania da maioria para a tirania de minorias pode ser analisada, antes de mais, a partir da emergência do fenómeno da propaganda, em todas as suas configuraçóes e áreas específicas, desde a esfera política à económica. Como escreve Bernays:

«Independentemente da atitude que se escolha face a esta condição, permanece um facto que em quase cada acto das nossas vidas diárias, seja na esfera da política ou dos negócios, na nossa conduta social ou no nosso pensamento ético, somos dominados pelo relativamente pequeno número de pessoas que compreendem os processos mentais e os padrôes sociais das massas» (Bernays, 2005: 37-38).

É, então, a associação entre a propaganda e o exercício do poder, em todas as suas dimensôes e esferas, associação característica do século XX, que torna, à partida, ultrapassada a relação simples estabelecida por Mill entre uma tirania exercida pelos costumes da maioria e uma liberdade individual que não poderia deixar de ser, diante dela, politicamente protegida. A partir do século XX, poder-se-ia dizer que esta relação entre a tirania da maioria e a liberdade individual, tal como Mill a aborda no século XIX, não propriamente desaparece, mas transforma-se de um modo radical, na medida em que a tirania da maioria se converte cada vez mais na tirania de minorias que, através de técnicas de propaganda crescentemente sofisticadas, configuram a própria maioria de acordo com as suas representaçôes, isto é, moldam e formam a própria maioria nos seus pensamentos, desejos e sentimentos através de técnicas que progressivamente a despojam de qualquer característica genuína. 
Foi a emergência da propaganda, no seu uso específico como propaganda política, que esteve subjacente às grandes revoluçóes totalitárias no século XX, nas quais minorias partidárias, considerando-se a si mesmas esclarecidas e fazendo uso de técnicas cada vez mais penetrantes e subtis, procuraram transformar radicalmente a sociedade através de uma acção directa sobre a mente e o coração dos homens individuais, configurando o seu modo de pensar e de sentir, a representação do seu passado e do seu futuro, na medida em que nenhuma parte da vida destes mesmos homens, por mais ínfima que fosse, deveria conseguir furtar-se ao poder da sua intervenção. É essencialmente esta configuração da totalidade dos aspectos da vida humana por um poder que a constitui como vida totalmente exposta a esse mesmo poder que se encontra na base originária do conceito de totalitarismo. Através da exposiçáo total da vida individual à propaganda exercida pelo poder totalitário de uma minoria, este mesmo poder sustenta-se na promoçáo, no seio da maioria ou das massas, de uma representação da sua identidade presente e da sua história passada, ou seja, numa obra de «engenharia social» cujo sentido último consiste em deste modo - para usar a expressão de George Orwell - controlar o futuro e perpetuar o poder. Assim, o despojamento da capacidade de ensaiar algo novo, ou sequer de pensar em qualquer futuro alternativo, não poderia deixar de ser a consequência última inevitável do poder sobre o indivíduo exercido não por costumes sedimentados numa experiência de vida em comum ou por tradiçóes há muito enraizadas na vida social, mas pelas acçôes de intenção libertadora de minorias que, concebendo-se a si mesmas como "esclarecidas», exerceriam o seu poder através da propaganda. Como escreve Hannah Arendt acerca da manipulação do passado pela propaganda destas minorias:

«Se o passado e o presente forem tratados como partes do futuro - isto é, reconduzidos para o seu anterior estado de potencialidade - a esfera política é privada não só da sua principal força estabilizadora, mas do ponto inicial a partir do qual se pode mudar, começar algo novo. Aquilo que então começa é a mudança constante e o arrastamento numa completa esterilidade que são características de muitas novas naçôes que têm a má sorte de nascerem numa era da propaganda» (Arendt, 1993: 258).

No entanto, se a substituição da tirania da maioria pela tirania de minorias se manifesta, antes de mais, na emergência das experiências políticas totalitárias do século XX, interessa ter em conta que um tal fenómeno está longe de se esgotar nestas mesmas experiências. E é precisamente para o carácter abrangente e multifacetado deste fenómeno que as reflexôes de Mill apontam, no momento em que reflectem em torno da aniquilação da originalidade dos indivíduos singulares não pela acção política dos governos e das magistraturas, mas pelos hábitos, pelos costumes, pelos preconceitos e perspectivas morais partilhadas pela maioria da gente vulgar numa sociedade. Através do fenómeno da propaganda, e através da mobilização da sociedade por minorias fortemente empenhadas na sua transformação radical, o século XX vê despontar formas de subordinação do indivíduo à sociedade que certamente não se podem limitar à violência explícita do exercício do poder político. Em vez de se reduzirem a tais fenómenos políticos extremos, dir-se-ia que estas formas de subordinação da singularidade dos indivíduos à acção homogeneizadora de «elites» pretensamente iluminadas, que se interpretam como mais livres, mais esclarecidas e mais modernas naquilo a que Christopher Lasch chamou uma «revolta das elites», estão presentes mesmo em sociedades democráticas e liberais. Lasch fala de uma «revolta das elites» em explícita contraposição à abordagem por Ortega 
y Gasset, na primeira metade do século XX, de uma «rebeliáo das massas» (Lasch, 1996: 25), mostrando que, no final deste século, se trata já não tanto da determinação do indivíduo pelos preconceitos morais do vulgo, ou da sua indiferenciação em relação à massa, mas da mobilização da própria massa por «elites» que exercem o seu poder através dela, embora sem com ela se confundirem. É justamente a omnipresença desta subordinação do indivíduo a massas formadas e mobilizadas por elites pretensamente iluminadas que pode permitir compreender, ao longo do século XX, toda uma reflexão em torno do modo como uma sociedade agitada pelo ímpeto de uma transformação social rápida e constante não pode deixar de hostilizar a originalidade singular e o pensamento livre.

Um exemplo desta reflexão encontra-se no pensamento de Leo Strauss, cuja alusão à necessidade de um renascimento da filosofia política clássica talvez encontre aqui, em última análise, o seu fundamento inconfessado. Se a transformação da sociedade por minorias militantes teria necessariamente de resultar numa crescente hostilização social de qualquer pensamento delas divergente, a filosofia, enquanto questionamento sempre radical e subversivo, não poderia deixar de ser intrinsecamente hostilizada pela própria sociedade. Seria nessa medida que a filosofia requereria, segundo Strauss, o cultivo de uma escrita esotérica: uma escrita capaz de expressar entre linhas, de um modo socialmente tolerável, um pensamento que se subtrai sempre aos padrôes estritos daquilo que é politicamente consentido. É então a partir da experiência da sociedade sua contemporânea, marcada pela agitação da propaganda de elites iluminadas, que Strauss parte do princípio de uma incompatibilidade fundamental entre filosofia e sociedade, de uma hostilidade essencial desta em relação àquela, procurando encontrar na atitude dos autores clássicos o testemunho mais explícito da sua própria experiência. É neste sentido que ele pode descrever a atitude dos filósofos políticos clássicos, que se trataria de reavivar na contemporaneidade, do seguinte modo:

«Eles acreditavam que o fosso que separava «o sábio» e «o vulgo» era um facto básico da natureza humana que não poderia ser influenciado por qualquer progresso da educação popular: a filosofia, ou ciência, era essencialmente um privilégio «dos poucos». Eles estavam convencidos de que a filosofia enquanto tal era suspeita para e era odiada pela maioria dos homens» (Strauss, 1988: 34).

Do mesmo modo, é a ideia desta intrínseca hostilidade da maioria mobilizada pela minoria militante em relação a toda a singularidade original que se expressa nas reflexões de Walter Lippmann, em 1955, em torno da necessidade da «renovação» de uma «filosofia pública», diante de um poder que ele mesmo tinha analisado, em 1922, como uma capacidade propagandística de, junto da maioria do público, «manufacturar o consenso» ou "criar o consenso» (Lippmann, 1997: 158). Segundo Lippmann, uma tal filosofia pública, que deveria tentar contrariar a tirania de minorias actuantes através da propaganda, não poderia deixar de consistir numa recuperação pela vida pública das sociedades modernas de um conjunto de "tradiçóes» cujo cultivo, longe de escravizar a alma individual, seria precisamente a condição da sua liberdade. Como escreve Lippmann:

«De um modo crescente, as pessoas sáo alienadas dos princípios interiores das suas instituições. A questão é se e como esta alienação pode ser ultrapassada, e a ruptura das tradições de civilidade reparada. [...] A questão premente é se e, se assim for, como os homens modernos poderão estabelecer um contacto vital com as tradiçóes perdidas da civilidade» (Lippmann, 1955: 80). 
Reflexôes tão diferentes como as de Walter Lippmann ou de Leo Strauss, evocando desde a recuperação pela sociedade das suas «tradiçóes de civilidade», perdidas às mãos da sua mobilização pela propaganda, até à "escrita esotérica» da filosofia face a uma hostilidade intrínseca e essencialmente constitutiva dessa mesma sociedade, ou seja, reflexôes tão diferentes em torno da transformação da sociedade numa instância crescentemente hostil ao pensamento livre e à diferença, mesmo quando tal diferença é proclamada como um princípio, indicam que a substituição da tirania da maioria evocada por Mill pela tirania de minorias mobilizadas e militantes se constitui como um fenómeno generalizado, transversal e crescente ao longo do século XX. Reflectindo sobre a sua transversalidade crescente, poder-se-ia dizer até que ele é hoje generalizado também no início do século XXI. Assim, dir-se-ia que, nas sociedades democráticas e liberais, a emergência de minorias sociais mobilizadoras se configurou - e se configura ainda hoje - através de fenómenos muito variados, cada vez mais diversos e sofisticados, mas que reproduzem, no essencial, a mesma estrutura de relação de poder, segundo a qual uma minoria social, concebendo-se como uma minoria esclarecida, ou seja, representando-se e apresentando-se a si mesma, implícita ou explicitamente, como a antecipação do que deverá ser o futuro, procura transformar aceleradamente a sociedade no sentido do advento deste mesmo futuro.

$\mathrm{Na}$ segunda metade do século XX, foi esta estrutura que se reproduziu, por exemplo, nas grandes revoltas estudantis soixante-huitards e nos seus sucedâneos simbólicos europeus e americanos, no momento em que a minoria pertencente a uma geraçáo, impondo-se socialmente, inaugurou um projecto de conformação de toda a sociedade não apenas a um modo comum de pensar, mas a uma «visão do mundo» e a uma sensibilidade padronizadas, caracterizadas pela rejeição do peso das tradiçôes e dos "cânones totalitários» do passado. Como escreveu Élisabeth Lévy, num livro em que analisa as consequências deste movimento na cultura francesa contemporânea:

«Alguns habitantes mais ou menos ilustres da soixantehuitardie estão doravante fundamentalmente convencidos de que tudo aquilo que releva do passado é condenável em bloco. Eles pensam sinceramente ter libertado o mundo das antigas opressôes. [...] Somos para sempre jovens e temos razão em tudo, afirmam os adolescentes de cabelos grisalhos que, à cabeça dos media e das empresas - os verdadeiros lugares do poder -, impóem os seus valores e os seus interesses ao conjunto da sociedade» (Lévy, 2002: 375).

Do mesmo modo, é também a partir desta estrutura de poder que pode ser compreendida a actual tendência da política europeia para actuar de um modo terapêutico junto de tradiçóes, "visóes do mundo» ou práticas sociais consideradas como resíduos de um passado obscuro e preconceituoso, assim como a crescente inclinação de muitos Estados europeus para se constituírem como "Estados terapêuticos», que não hesitam em proibir a ostentação pública de símbolos religiosos considerados opressores ou chocantes, ou em criminalizar a expressão de opiniôes consideradas indecentes, ofensivas para a «memória histórica» e reveladoras de uma insensibilidade patológica. Como escreve Paul Edward Gottfried: «A ideologia terapêutica reinante requer que a maioria da populaçáo do Ocidente trabalhe para se livrar das taras da sua história ancestral» (Gottfried, 2002: 141).

No começo do século XXI, é também a estrutura de poder de minorias mobilizadas por esta «ideologia terapêutica» que se manifesta nos próprios centros de formação e de transmissão do saber e da cultura, sobretudo nas universidades, no momento em que as 
«humanidades» nelas cultivadas, colocadas ao serviço de "políticas de sensibilização", muitas vezes se convertem em instrumentos edificantes de padronização moral, de correcção política e de transformação social. Nos Estados Unidos, Roger Kimball levou a cabo uma provocadora mas lúcida análise deste processo:

"Quando os filhos dos anos sessenta receberam as suas cátedras e reitorados, não abandonaram o sonho da transformação cultural radical; foram implementá-lo. Agora, em vez de perturbar as aulas, estão a dar aulas; em vez de tentar destruir fisicamente as nossas instituiçôes educativas, estão a subvertê-las por dentro» (Kimball, 1998: 191-192).

A tendência crescente para a transformação da escola em geral, e das universidades em particular, em instrumentos de padronização social, numa normalização da sensibilidade que se estende desde o controlo do pensamento pela political correcteness até à vigilância do discurso por meio de speech codes, é hoje porventura a mais alarmante manifestação da substituição daquilo que Mill pensou como a tirania da maioria, na sua relação com a liberdade individual, pelo poder de minorias comprometidas com uma acção transformadora, homogeneizadora e sensibilizadora que se exerce de modo cada vez mais difuso e variado. Tendo em conta a proliferação de fenómenos desta natureza, uma reflexão sobre $\mathrm{On} L i$ berty, e sobre os seus argumentos em defesa da liberdade individual, poderá certamente contribuir para uma confrontação crítica, séria e profunda com estes mesmos fenómenos, surpreendendo neles, apesar das suas diferenças e da sua pluralidade, os traços de uma estrutura comum.

\section{Bibliografia}

ARENDT, Hannah (1993), Between Past and Future, New York, Penguin Books. BERLIN, Isaiah, (2004), Liberty, ed. Henry Hardy, Oxford, Oxford University Press. BERNAYS, Edward (2005), Propaganda, New York, Ig Publishing.

GOTTFRIED, Paul Edward (2002), Multiculturalism and the Politics of Guilt: Toward a Secular Theocracy, Columbia \& London, University of Missouri Press.

KIMBALL, Roger (1998), Tenured Radicals, Chicago, Elephant Paperbacks.

LASCH, Christopher (1996), The Revolt of the Elites and the Betrayal of Democracy, New York \& London, W. W.

Norton \& Company.

LÉVY, Élisabeth (2002), Les maîtres censeurs, Paris, Lattès.

LIPPMANN, Walter (1955), The Public Philosophy, New York, Mentor Books.

LIPPMANN, Walter (1997), Public Opinion, New York, Free Press Paperbacks.

MILL, John Stuart (1998), On Liberty and Other Essays, ed. John Gray, Oxford, Oxford University Press.

STRAUSS, Leo (1988), Persecution and the Art of Writing, Chicago \& London, The University of Chicago Press. 